\title{
Challenges in Quantifying Greenhouse Gas Impacts of Waste- Based Biofuels in EU and US Biofuel Policies: Case Study of Butanol and Ethanol Production from Municipal Solid Waste
}

\author{
Fanran Meng, and Jon McKechnie
}

Environ. Sci. Technol., Just Accepted Manuscript • DOI: 10.1021/acs.est.9b04286 • Publication Date (Web): 25 Sep 2019

Downloaded from pubs.acs.org on September 28, 2019

\section{Just Accepted}

"Just Accepted" manuscripts have been peer-reviewed and accepted for publication. They are posted online prior to technical editing, formatting for publication and author proofing. The American Chemical Society provides "Just Accepted" as a service to the research community to expedite the dissemination of scientific material as soon as possible after acceptance. "Just Accepted" manuscripts appear in full in PDF format accompanied by an HTML abstract. "Just Accepted" manuscripts have been fully peer reviewed, but should not be considered the official version of record. They are citable by the Digital Object Identifier (DOI®). "Just Accepted" is an optional service offered to authors. Therefore, the "Just Accepted" Web site may not include all articles that will be published in the journal. After a manuscript is technically edited and formatted, it will be removed from the "Just Accepted" Web site and published as an ASAP article. Note that technical editing may introduce minor changes to the manuscript text and/or graphics which could affect content, and all legal disclaimers and ethical guidelines that apply to the journal pertain. ACS cannot be held responsible for errors or consequences arising from the use of information contained in these "Just Accepted" manuscripts. 


\title{
Challenges in Quantifying Greenhouse Gas
}

\section{Impacts of Waste-Based Biofuels in EU and US}

\author{
Biofuel Policies: Case Study of Butanol and
}

\section{Ethanol Production from Municipal Solid Waste}

\author{
Fanran Meng ${ }^{t^{*}}$, Jon McKechniet \\ † Sustainable Process Technologies Group, Faculty of Engineering, University of \\ Nottingham, Nottingham NG7 2RD, U.K. \\ *Corresponding author. E-mail: Fanran.Meng@nottingham.ac.uk
}




\section{Abstract}

3 Conversion of wastes to biofuels is a promising route to provide renewable low-

4 carbon fuels, based on a low- or negative-cost feedstock whose use can avoid

5 negative environmental impacts of conventional waste treatment. However, current

6 policies that employ LCA as a quantitative measure are not adequate for assessing

7 this type of fuel, given their cross-sector interactions and multiple potential

8 product/service streams (energy, fuels, materials, waste treatment service). We

9 employ a case study of butanol and ethanol production from mixed municipal solid

10 waste to demonstrate the challenges in using life cycle assessment to appropriately

11 inform decision-makers. Greenhouse gas emissions results vary from -566

$12 \mathrm{gCO}_{2}$ eq./MJ $\mathrm{Mb}_{\text {biouel }}$ (under US policies that employ system expansion approach), to +86

$13 \mathrm{gCO}_{2}$ eq. $/ \mathrm{MJ}_{\text {biofuel }}$ and $+23 \mathrm{gCO}_{2}$ eq./MJ $/ \mathrm{M}_{\text {biofuel }}$ (under initial and current $\mathrm{EU}$ policies that

14 employ energy-based allocation), relative to gasoline emissions of $+94 \mathrm{gCO}_{2}$ eq. LCA

15 methods used in existing policies thus provide contradictory information to decision- 
16 makers regarding the potential for waste-based biofuels. A key factor differentiating

17 life cycle assessment methodologies is the inclusion of avoided impacts of

18 conventional waste treatment in US policies, and their exclusion in EU policies.

19 Present EU rules risk discouraging the valorisation of wastes to biofuels, and thus

20 forcing waste towards lower-value treatment processes and products.

21

22

23

24

25 Graphical abstract

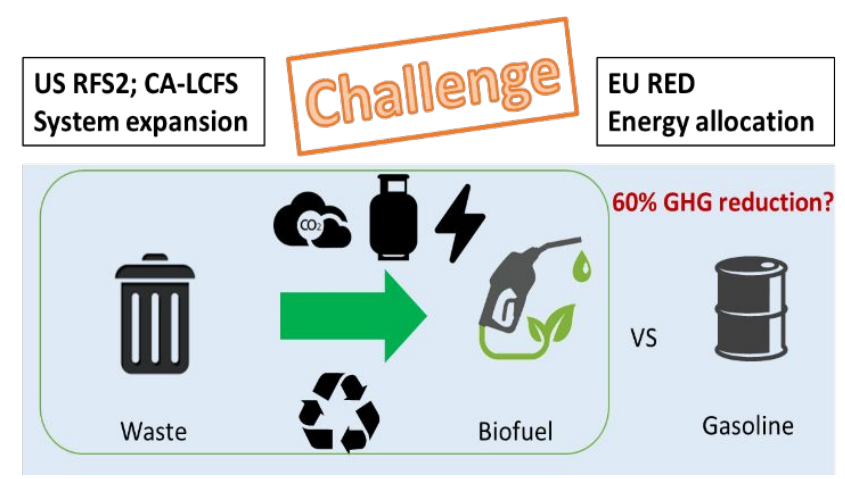




\section{Introduction}

28 Liquid biofuels can play a key role in the decarbonisation of the transport sector, and

29 have been studied extensively with life cycle assessment (LCA) tools to quantify their

30 net contribution to addressing greenhouse gas (GHG) emissions associated with

31 conventional, fossil fuels. LCA methodologies have been developed as a quantitative

32 element of transport fuel policies globally, wherein they are used to determine a fuel's

33 eligibility (US Energy Independence and Security Act; EU Renewable Energy

34 Directive) or to calculate its contribution to reducing emissions related to fuel use (e.g.,

35 California Low Carbon Fuel Standard). The development of waste-based fuels has

36 received significant attention as they can avoid land use implications of crop-based

37 biofuels (e.g., carbon stock reductions in biomass and soil pools; biodiversity impacts)

38 while also contributing to waste treatment objectives in the perspective of a more

39 circular economy. However, waste-to-energy systems are complex in view of their

40 multi-functional nature: they provide a waste treatment service and can produce a

41 diverse range of material and energy co-products, as well as the primary liquid fuel 
42 product. LCA frameworks employed in existing policies which were developed to

43 principally consider crop- and agriculture/forestry residue-based biofuels. These

44 approaches face challenges in evaluating biofuels produced from more complex,

45 mixed waste feedstock streams and in accounting for interactions between the waste

46 treatment and energy sectors.

47 LCA plays a central and quantitative role in global policies aimed at reducing GHG

48 emissions of transport fuels. In the EU, the Fuel Quality Directive regulates a minimum

49 of $6 \%$ reduction of the life cycle GHG intensity of transport fuels by 2020 compared to

502010 level, which can be achieved through the use of biofuels as one means. ${ }^{1}$ In order

51 to be considered as renewable biofuels, life cycle GHG emissions must be at least

$5250 \%$ lower than from the fossil fuel they replace and $60 \%$ for newer installations from

53 January 2018. Similar thresholds are present in US policy: the Energy Independence

54 and Security Act (EISA) requires biofuels to achieve a life cycle GHG reduction

55 threshold as compared to a 2005 petroleum baseline for different types of biofuels

56 (e.g., $60 \%$ reduction for cellulosic biofuel, $50 \%$ reduction for advanced biofuel from 
57 renewable biomass, and $20 \%$ reduction for conventional biofuels). Low Carbon Fuel

58 Standards (LCFS), which have been implemented in California and other North

59 American jurisdictions, ${ }^{2,} 3$ employ a GHG-intensity target to encourage low-carbon

60 transport fuels.

61 LCA-based biofuel policies differ substantially in their life cycle GHG emission

62 calculation methodologies, which has substantial impact on the assessed GHG

63 emissions of fuels. Prior studies have demonstrated how LCA study factors, including

64 definition of system boundaries, co-product allocation methods, and selection of

65 functional units, can return very different resutls for the same feedstock/fuel pathway. ${ }^{4-}$

6610 The EU RED and FQD policies are based on an attributional LCA methodology,

67 which attempts to isolate the impact of fuel production and use from connected

68 systems. Where fuel production processes result in multiple outputs, environmental

69 impacts are allocated between the primary fuel product and co-products on an energy

70 basis, ${ }^{11,12}$ and therefore the broader impacts of fuel production on co-product markets

71 is not considered. Numerous prior studies have evaluated biofuels using the EU 
72 methodology and have identified that this approach risks underestimating the

73 environmental benefit of biofuel systems by ignoring co-product use and

74 corresponding displacement of production elsewhere (e.g., ${ }^{7}$ ), particularly if co-

75 products do not have an energy content and therefore cannot be allocated an

76 environmental impact under the prescribed allocation method. ${ }^{13}$ This limitation is

77 particularly relevant for waste-based biofuels, the production of which may encourage

78 recovery of materials with no energy content (e.g., scrap metal and/or glass for

79 recycling). Further, wastes are attributed zero GHG emissions; ${ }^{11,12}$ as such, avoided

80 emissions due to diverting wastes from conventional treatment routes (e.g., landfill)

81 are not credited to the biofuel product. ${ }^{14}$ In contrast, the US EISA and North American

82 LCFS policies employ a partially consequential LCA methodology that aims more to

83 evaluate the change in GHG emissions arising from adoption of alternative fuels.

84 These policies employ system expansion to deal with multiple products, wherein the primary fuel product is "credited" with avoided emissions by assuming that co-products

86 would displace production elsewhere in the economy. Further, benefits of avoided 
87 waste treatment processes, such as landfilling, are also credited to the biofuel product

88 (e.g. $\left.{ }^{15}\right)$. With credits from co-products considered, biofuels can in some cases be

89 attributed with negative emissions: credits from co-products exceed the total

90 emissions associated with producing and using the fuel (e.g., $\left.{ }^{16,17}\right)$. Such results can

91 be misleading, as the assessed biofuels do not achieve an absolute reduction of

92 atmospheric GHGs, but rather a relative reduction in GHG emissions considering the

93 production displaced by co-products. For waste-derived biofuels, such distortions may

94 be amplified given the potential for a wider range and greater quantity of co-products.

95 Overall, while existing policies on the surface have similar GHG emissions thresholds,

96 fuel eligibility is dependent on the specific assessment methodologies employed.

97 Ultimately, these methodologies diverge in terms of the "question" they are asking,

98 and therefore whether fuels are evalauted in terms of the overall environmental

99 impacts of the system producing biofuels, or a share of impacts that can be directly

100 attributed to the fuel product in isolation. 
101 Waste-based biofuels can provide policy-relevant benefits beyond provision of low-

102 carbon transport fuels. By diverting waste feedstocks from conventional treatment

103 routes (landfilling; incineration), the high cost of disposal by these routes can be

104 avoided. This is particularly relevant in jurisdictions such as the UK where landfill tax,

105 currently $£ 91.35 /$ tonne, or approximately $\$ 120$ USD/tonne, ${ }^{18}$ greatly increases the cost

106 of disposal by this route. Waste utilisation for fuel production can also encourage the

107 recovery of other materials (e.g., scrap metal, plastic for recycling), and avoiding

108 significant GHG emissions associated with landfilling biogenic wastes (e.g. ${ }^{19}$ ) or

109 incinerating plastic-based wastes (e.g., $\left.{ }^{20}\right)$.

110 Specific support for waste-derived biofuels varies greatly between regions. The EU

111 RED requires $10 \%$ renewable energy share in transport fuel consumption by 2020 . A

112 cap limiting first-generation biofuels ${ }^{21}$ to $7 \%$ share indirectly supports second- and

113 third- generation fuels from non-crop feedstocks, including waste-based biofuels.. In

114 the UK, the Renewable Transport Fuel Obligation provides a stricter limitation on crop-

115 based fuels and further incentivises waste-based fuels by awarding double Renewable 
116 Transport Fuel Certificates (RTFC) per litre of liquid renewable fuels derived from

117 certain waste or residue feedstocks; these credits are tradeable and have a market

118 value of $£ 0.18$ to $£ 0.24$ per RTFC, ${ }^{22}$ or approximately $\$ 0.25$ to $\$ 0.30$ USD per RTFC,

119 thus financially supporting waste-based fuels. Under the US EISA and California

120 LCFS, there is no specific support for waste-derived fuels.

121 Waste-based biofuel production systems are complex to evaluate due to their cross-

122 sector interactions (waste and energy/transport sectors) and the wide range of

123 potential co-products. In addition to producing a fuel output, any system producing

124 biofuels from wastes may: 1) avoid current waste treatment processes; 2) enable the

125 recovery of recyclable materials; and 3) co-produce other energy outputs (e.g., excess

126 electricity; heat; fuels). For policies to be comprehensively informed, and for business

127 to make appropriate decisions in response to policies, an appropriate LCA framework

128 is needed to account for this complexity. Therefore, we have developed a case study

129 to explore the implications of LCA methodology decisions on assessed GHG

130 emissions and primary energy demand and to reflect on how these varying model 
131 outputs are capable of answering different questions about waste-based biofuels. The

132 case study considers a MSW to acetone-butanol-ethanol conversion process based

133 on an autoclave mechanical heat treatment process and subsequent fermentation of

134 the biomass fibre to liquid biofuels (butanol, ethanol) and other co-products.

135 Alternative system boundaries and allocation approaches are applied in the context of

136 LCA frameworks within EU and US policies. The results are compared and integrated

137 to more meaningfully inform policymakers and industry on the net GHG implications

138 of waste to biofuel systems.

1392 Methods

140 In this study, we compare life cycle methodologies to evaluate waste-to-biofuels

141 systems and consider how information from the differing approaches can help to

142 inform decision-making. We map these methodology decisions to current and recent

143 biofuels policies in Europe and North America to consider how LCA methodologies 
144 influence the assessed GHG emissions of biofuels. A case study scenario of liquid

145 biofuel (butanol, ethanol) production from municipal solid waste (MSW) is employed.

\subsection{LCA methodologies}

147 The overall environmental performance of converting the organic content of MSW to

148 biofuels and concurrently avoiding current waste treatment practices is evaluated.

149 Given the wide range of potential products/co-products (energy outputs; recovered

150 metals/glass/plastics) with diverse materials and energy market applications (see

151 Figure 1), a set of LCA methodologies are deployed to better understand how

152 decisions on how to allocate impacts between liquid biofuel product and the energy

153 and material co-products influence results. We consider the following set of LCA

154 methodologies:

1) US EISA / California LCFS: Avoided waste treatment processes included (credit to primary biofuel product); all co-products evaluated with system expansion (credit to primary biofuel product) (see Section 1.1.1 in SI) 
2) EU RED I (original policy): Avoided waste treatment excluded; electricity coproduct evaluated with system expansion (credit to primary biofuel product); all other co-products evaluated by energy allocation (see Section 1.1.2.1 in

3) EU RED II (current policy): Avoided waste treatment excluded; exergy allocation of electricity and heat co-products; all other co-products evaluated by energy allocation (see Section 1.1.2.2 in SI)

4) Mass-based allocation alternative: Avoided waste treatment may or may not be included; all co-products evaluated by mass-based allocation (see Section

5) Economic allocation alternative: Avoided waste treatment may or may not be included; all co-products evaluated by economic value allocation (see Section

$$
1.1 .3 \text { in SI) }
$$

171 The LCA models are developed in GaBi 8.2 using Ecoinvent 3.3 inventory

172 databases, following ISO Standards 14040 and $14044 .{ }^{23}, 24$ Two environmental 
173 impacts are quantified: global warming potential (GWP), based on the most recent

174 IPCC 100-year GWP factors to quantify GWP in terms of $\mathrm{CO}_{2}$ equivalents $\left(\mathrm{CO}_{2} \text { eq. }\right)^{25}$

175 and primary energy demand (PED) in terms of MJ.

176

177

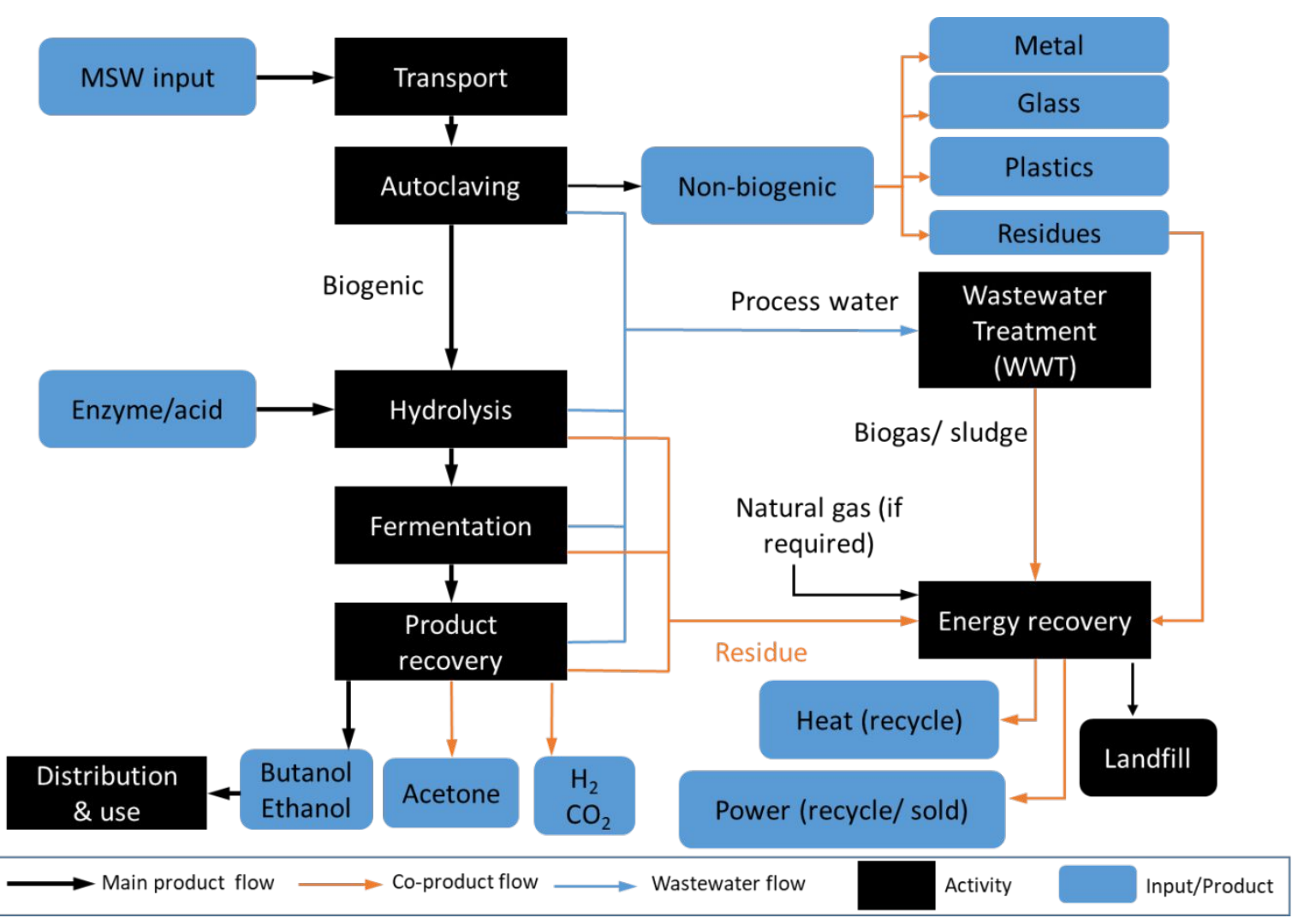

179 Figure 1 Schematic representation of life cycle assessment of butanol and ethanol

180 from MSW. 
181 The scope and functional unit LCA models are developed to evaluate the case study

182 scenario of MSW conversion to acetone-butanol-ethanol based on an autoclave pre-

183 treatment. Autoclave pre-treatment converts biogenic content to a biofibre material,

184 and enables the recovery of sterilised metal, glass, and plastic materials. The biomass

185 fibre is subsequently converted to liquid biofuels (ethanol, butanol), hydrogen, acetone

186 via hydrolysis and fermentation, and heat/power from combustion of unconverted

187 residual biomass material. The functional unit is one $\mathrm{MJ}$ of liquid biofuel (butanol and

188 ethanol), denoted as $\mathrm{MJ}_{\text {biofuel. }}$ Results are also considered on the basis of 1 tonne

189 MSW treated. A schematic process flow diagram defining the system boundaries is

190 shown in Figure 1. The system boundaries start from the sorting and transportation of

191 MSW. Prior energy use and environmental burdens of the processes and products

192 that generated MSW are excluded in this study.

\section{$193 \quad 2.2$ Waste composition and avoided treatment}

194 The waste composition used is representative of the UK MSW with the following wet

195 composition by mass: paper and cardboard (22\%), food waste (17\%), wood (8.7\%), 
196 plastic $(22 \%)$, glass $(1 \%)$, garden waste $(3 \%)$, metals $(4 \%)$, textiles $(6.6 \%)$ and others

$197(15.7 \%){ }^{26}$ The lignocellulosic content of total MSW is $53 \%$ on the wet basis and its

198 moisture content is $40 \%$.

199 By diverting wastes to biofuel production, conventional treatment processes are

200 avoided. We assume that incoming waste would otherwise be treated by incineration

201 (71\%) and landfilling (29\%), based on current practices in UK. ${ }^{27}$ Considerations of

202 credits related to inclusion/exclusion of avoided waste treatment under different

203 allocation approaches are detailed in Section 2.2. Implications of considering avoided

204 waste treatment are discussed in Section 3.1. For landfill and incineration options, we

205 draw on the results from the Ecoinvent database and literature. ${ }^{20,}{ }^{28}$ For landfill gas

206 recovery, it is assumed that $62 \%$ of biogas is recovered $(52 \%$ for energy recovery and

$20710 \%$ for flaring) and $38 \%$ is emitted. ${ }^{19}$

$208 \quad 2.3$ Waste - to - biofuel process

209 The MSW-to-biofuel production process has been previously modelled based on a

210 demonstration plant operation ${ }^{29}$ and further details on the process are available in the 
211 Supporting Information (SI). The system starts with the pretreatment autoclave

212 process, based on a working facility developed by Wilson BioChemical. ${ }^{30} \mathrm{MSW}$ is input

213 to the autoclave and treated with steam at moderate temperature $\left(160^{\circ} \mathrm{C}\right.$ for two

214 hours). The organic content of the MSW is converted into a biomass fibre within the

215 autoclave, which is then recovered to be used as feedstock in ABE production via

216 enzymatic hydrolysis and fermentation. Energy recovery from unconverted biomass

217 and biogas generated in wastewater treatment is sufficient to provide all heat and

218 power requirements of the integrated autoclave/biofuel production process, with

219 excess electricity exported to the grid. Recyclable material streams (ferrous \& non-

220 ferrous metals, glass, plastic, wood and textiles) are sterilised within the autoclave and

221 separated from the output stream for subsequent material recovery. All remaining

222 material is classed as waste and sent to incineration/landfill at the same proportions

223 as current waste treatment (see Section 2.2).

224 Biogenic fibre derived from MSW differs significantly from more conventional biofuel

225 feedstocks, exhibiting a comparatively low total sugar content ( $45 \%$ glucose and $5 \%$ 
226 xylose) and the presence of contaminants that inhibit enzymatic hydrolysis. These

227 factors ultimately limit the liquid biofuel yield. Correspondingly, greater quantities of

228 residual biomass material are available for energy recovery, resulting in a

229 comparatively high output of co-product electricity. Table S1 in the SI details the

230 outputs of the process and their respective destinations.

\section{$231 \quad 2.4 \quad$ Co-product allocation}

232 Co-products arising from the conversion of MSW to liquid biofuel can be classified

233 as energy products (hydrogen; excess electricity); chemicals (acetone); and scrap

234 materials (metal, plastic and glass) (Figure 1). Allocation methods differ between each

235 of the LCA methodologies considered.

236 The US EISA and California LCFS employ a system expansion approach, wherein

237 co-products are assumed to displace production elsewhere, with associated avoided

238 impacts credited to the primary biofuel product. We assume direct displacement for

239 co-product electricity (avoiding average UK grid generation), hydrogen (avoiding

240 production from fossil fuel sources), and acetone (avoiding primary production). Scrap 
241 materials require further processing before they displace alternative production in a

242 market; these downstream processes to convert scrap to saleable materials are

243 included in the model. Plastic waste, of average composition ${ }^{31}$ is input to a mechanical

244 recycling process to recover, per 1000kg input, $236 \mathrm{~kg} \mathrm{PET}, 63 \mathrm{~kg} \mathrm{PP}, 122 \mathrm{~kg} \mathrm{PE}$, and

$2451 \mathrm{~kg} \mathrm{PVC.}{ }^{32}$ Recovered materials are assumed to displace primary production.

246 Unrecyclable materials (films, wastes and residues, 580kg) are disposed of by

247 incineration (71\%) and landfill (29\%). ${ }^{27}$ For metals recycling, we use inventory data

248 from Gabi and Ecoinvent database. ${ }^{28,33}$ Glass is assumed to be recovered to replace

249 aggregates and result in negligible net change in GHG emissions and PED. ${ }^{34}$

250 The EU RED methodologies are based on allocating impacts between primary and

251 co-products on an energy content basis. The original policy, EU RED I, requires

252 allocation based on the lower heating value of the products, with the exception of

253 excess electricity which addressed by system expansion. For the EU RED I scenario

254 we assume co-product electricity displaces average UK grid generation. EU RED II

255 employs allocation for co-generated heat and electricity based on their respective 
256 exergy content, which accounts for the temperature (i.e., quality) of the heat product.

257 All other co-products are considered with energy allocation. Table S4 in the SI

258 presents characteristics and values of exergy allocation. For both EU RED I and II,

259 there is no allocation to non-energy products (recovered metal, plastic). Partitioning

260 ratios are shown in Table 1.

261 Two additional allocation methods are considered that are able to account for non-

262 energy co-products. Mass allocation distributes the GHG emissions associated with

263 main products and co-products based on their respective mass. A two-stage mass

264 allocation is employed: first, upstream processes and waste pre-treatment are

265 allocated between the biofibre and non-biogenic content on a mass basis (see Figure

266 S5 in the SI). Second, we allocate a share of biofuel production impacts to co-product

267 acetone and hydrogen (electricity and heat have no allocation as they have no mass).

268 Finally, economic allocation apportions impacts between co-products on the basis of

269 their financial value. We conduct the allocation considering the overall production 
270 outputs, as intermediate product (biofibre) does not have a financial value (see Table 271 1).

272 Table 1 Partitioning ratio for mass, energy, and economic allocation.

\begin{tabular}{|c|c|c|c|c|c|c|c|}
\hline \multirow[b]{2}{*}{$\begin{array}{l}\text { Allocatio } \\
\mathrm{n}\end{array}$} & \multicolumn{2}{|c|}{ 1-Autoclave } & \multicolumn{5}{|c|}{ 2-Biorefinery } \\
\hline & $\begin{array}{l}\text { Biogeni } \\
\text { c }\end{array}$ & $\begin{array}{l}\text { Non- } \\
\text { biogeni } \\
\text { c }\end{array}$ & $\begin{array}{l}\text { Butano } \\
\text { I and } \\
\text { ethano } \\
\text { I }\end{array}$ & $\begin{array}{l}\text { Aceton } \\
\mathrm{e}\end{array}$ & $\begin{array}{l}\text { Hydroge } \\
n\end{array}$ & $\begin{array}{l}\text { Electricit } \\
\text { y and } \\
\text { heat }\end{array}$ & $\begin{array}{l}\text { Recover } \\
\text { ed } \\
\text { plastic, } \\
\text { metal, } \\
\text { glass }\end{array}$ \\
\hline $\begin{array}{l}\text { Energy } \\
\text { value-EU } \\
\text { RED I }\end{array}$ & $30.7 \%$ & $69.3 \%$ & $61.5 \%$ & $22.3 \%$ & $16.1 \%$ & - & \\
\hline $\begin{array}{l}\text { Energy } \\
\text { value-EU } \\
\text { RED II }\end{array}$ & $30.7 \%$ & $69.3 \%$ & $8.5 \%$ & $3.1 \%$ & $2.2 \%$ & $86.3 \%$ & \\
\hline $\begin{array}{l}\text { Mass } \\
\text { value- } \\
\text { general }\end{array}$ & $53 \%$ & $47 \%$ & $3.2 \%$ & $1.3 \%$ & $0.2 \%$ & $\begin{array}{l}95.3 \% \\
\text { (as } \\
\text { biomass } \\
\text { fuel) }\end{array}$ & $\begin{array}{l}\text { (allocate } \\
\text { d at } \\
\text { autoclav } \\
\text { e) }\end{array}$ \\
\hline $\begin{array}{l}\text { Economi } \\
\text { c value }\end{array}$ & - & - & $23.8 \%$ & $6.1 \%$ & $2.3 . \%$ & $48 \%$ & $37.6 \%$ \\
\hline
\end{tabular}




\section{$273 \quad 3$ Results and Discussion}

\section{$274 \quad 3.1$ Greenhouse gas emissions evaluated under current policies}

275 Overall, the production of liquid biofuels (butanol, ethanol) from MSW achieves lower

276 GWP than the reference gasoline product. However, quantified impacts vary

277 substantially between the LCA methodologies considered.

278 Waste-derived biofuels achieve substantial reductions in GHG emissions and PED

279 relative to gasoline when employing the system expansion approach, as in US EISA

280 and CA LCFS policies. Negative GHG emissions (-600\% relative to gasoline) are

281 achieved, due in large part to the significant credit for avoiding landfilling and

282 incineration in current waste treatment $\left(-576 \mathrm{gCO}_{2}\right.$ eq. $\left./ \mathrm{MJ}_{\text {biofuel }}\right)$. Excluding avoided

283 waste treatment would still result in very low GHG emissions under system expansion

284 approach (11 $\mathrm{gCO}_{2}$ eq./MJ $/ \mathrm{Mbifuel}_{\text {) }}$ ) as a result of significant co-product credits for

285 electricity export and metals recovery (-166 and $-202 \mathrm{gCO}_{2} \mathrm{eq} . / \mathrm{MJ}_{\text {biofuel, }}$, respectively).

286 Recovery of plastics does not provide a significant net reduction in GHG emissions,

287 as recycling and residual waste disposal incurs similar emissions (418 
$288 \mathrm{gCO}_{2}$ eq. $\left./ \mathrm{MJ}_{\text {biofuel }}\right)$ as those associated with avoided primary plastic production (-446

$289 \mathrm{gCO}_{2}$ eq./MJ $\left.\mathrm{Mb}_{\text {biofuel }}\right)$, assuming $100 \%$ displacement with recovered plastics. If recycled

290 plastics are used in other markets, due to their potentially reduced quality relative to

291 primary plastics, this co-product credit may moderately decrease. ${ }^{32}$ Co-products of

292 acetone and hydrogen only contributes to $4 \%$ of the total credits (-30.34

$293 \mathrm{gCO}_{2}$ eq. $/ \mathrm{MJ}_{\text {biofuel }}$ ) (see Figure S7). It is noted in this case study, the relatively low sugar

294 yield by hydrolysis and correspondingly low biofuel yield results in larger quantities of

295 residual biomass available for co-product electricity production than with conventional

296 feedstocks. Major GHG emissions sources arise from the manufacture of enzymes

297 (187 $\mathrm{gCO}_{2}$ eq. $/ \mathrm{MJ}_{\text {biofuel }}$ ), included in the total biorefinery emissions indicated in Figure

298 2a (also see Table S6). Other process inputs ( $\mathrm{pH}$ control; fermentation nutrients;

299 microorganism) have smaller impacts, totalling $20.87 \mathrm{~g} \mathrm{CO}_{2} \mathrm{eq} / \mathrm{MJ}_{\text {biofuel. }}$. Treatment of

300 residual waste from autoclave has a large $\mathrm{GHG}$ emission of $141.01 \mathrm{~g} \mathrm{CO} \mathrm{Cq}_{2} / \mathrm{MJ}_{\text {biofuel }}$.

301 Collection and transport accounts for about 4\% while fuel distribution and use

302 accounts for less than $1 \%$ of the total PED and GHG emissions (see Figure S7 in the 
$303 \mathrm{SI}$. On balance, with substantially negative GHG emissions, the MSW-derived

304 biofuels would by far surpass the eligibility requirements for the US EISA policy.

305 GHG emissions are substantially higher when allocation is used to evaluate the

306 MSW-derived biofuels. The initial RED I policy employs energy allocation between

307 products, with the exception of co-product electricity: excess electricity is evaluated by

308 system expansion, and the credit from displacing generation elsewhere is allocated

309 between the biorefinery products. No impacts are allocated to the recovered metal and

310 glass co-products, as these material do not have an energy content. RED I results in

$311 \mathrm{GHG}$ emissions of $86 \mathrm{gCO}_{2}$ eq. $/ \mathrm{MJ}_{\text {biofuel, }}$ achieving only a minor reduction of $9 \%$ relative

312 to gasoline and therefore would not qualify as an eligible biofuel under the policy.

313 Enzyme production ${ }^{29}$ represents approximately $85 \%$ of net emissions allocated to

314 biofuel production. The higher net GHG emissions, relative to the system expansion

315 approach, result from the exclusion of avoided waste treatment and the apportioning

316 of the co-product electricity credit between biofuels and other products: of the total 102

$317 \mathrm{gCO}_{2} \mathrm{eq} / \mathrm{MJ}_{\text {biofuel }}$ credit, only $31 \mathrm{gCO}_{2}$ eq. is credited to the biofuel product. Thus, 
318 although the production of biofuels from MSW would achieve significant overall GHG

319 reductions when all products are considered, this pathway would not be eligible under

320 the original RED policy.

321 In contrast, under the revised RED II policy, the MSW-derived biofuels would be

322 eligible, with overall $\mathrm{GHG}$ emissions of $23 \mathrm{gCO}_{2} \mathrm{eq} / \mathrm{MJ}_{\text {biofuel, }}$ a reduction of $75 \%$. With

323 exergy allocation applied to the co-product electricity and heat, a large share of

324 biorefinery emissions (86\%) are applied to these outputs; correspondingly, fewer

325 emissions are attributed to the biofuel product. Excess electricity is attributed with

$326 \mathrm{GHG}$ emissions of $86 \mathrm{gCO}_{2} \mathrm{eq} / \mathrm{MJ}$, which represents a $12 \%$ reduction compared to UK

327 grid electricity mix ${ }^{35}$ (see Table S5 in the SI). Enzyme production still contributes the

328 largest share of GHG emissions attributed to the biofuel outputs (68\%).

329 By excluding avoided waste treatment impacts, the RED I and RED II policies ignore

330 an important service provided by waste valorisation systems of diverting and treating

331 waste that would otherwise be destined to landfill/incineration. Inclusion of avoided

332 waste treatment would reduce the GHG emissions assessed under RED I and RED 
333 II. Apportioning credits related to avoided landfilling and incineration processes would

334 result in net $\mathrm{GHG}$ emissions of $-22 \mathrm{gCO}_{2} \mathrm{eq} / \mathrm{MJ}_{\text {biofuel }}$ and $8 \mathrm{gCO}_{2} \mathrm{eq} / \mathrm{MJ}_{\text {biofuel }}$ for RED I

335 and RED II, respectively. In both cases, biofuel products would achieve eligibility, with

336 net emissions more completely quantified by including the impact of waste diversion

337 from conventional routes to input to the production system.

338 3.1.1 Greenhouse gas emissions evaluated under alternative allocation methods

339 Mass and economic allocation are considered as alternatives to system expansion

340 and energy allocation approaches, as these allow allocation to non-energy products

341 (recovered metal, glass) (see Figure 2a and Table S6). With mass allocation, only a

342 small fraction of impacts are allocated to the biofuel products, which represent only

$3433 \%$ of product outputs by mass. As a consequence, biofuels are attributed a small net

$344 \mathrm{GHG}$ emission of $9.2 \mathrm{gCO}_{2} \mathrm{eq} . / \mathrm{MJ}_{\text {biofuel, }}$ or $-0.4 \mathrm{gCO}_{2} \mathrm{eq} . / \mathrm{MJ}_{\text {biofuel }}$ if avoided waste

345 treatment is considered. A higher share of emissions are attributed to the biofuel

346 products under economic allocation (36\%) due to the comparatively high value of 
347 these outputs relative to other products, resulting in net GHG emissions of 56

$348 \mathrm{gCO}_{2}$ eq. $\mathrm{MJ}_{\text {biofuel, }}$ or $-81 \mathrm{gCO}_{2}$ eq. $/ \mathrm{MJ}_{\text {biofuel }}$ if avoided waste treatment is considered.

\section{$349 \quad 3.2 \quad$ Primary energy demand}

350 MSW-derived biofuels are associated with lower PED than conventional gasoline

351 fuel. As with GWP, however, the calculated PED varies substantially between LCA

352 methodologies considered (see Figure $2 \mathrm{~b}$ and Table S6). Applying system expansion,

353 as in the US EISA and CA LCFS policies, returns a strongly negative value, with PED

354 at $-1,238 \%$ relative to gasoline. The large co-product credit associated with recovered

355 plastics is principally responsible, by avoiding both the consumption of feedstock and

356 process energy required for plastics manufacture $\left(-12.9 \mathrm{MJ} / \mathrm{MJ}_{\text {biofuel }}\right)$. Further, the

357 disposal of most residual plastic waste by incineration provides useful energy outputs

358 (heat, electricity) which are credited to the primary biofuel product. Thus plastic

359 recycling is much more beneficial from a PED perspective than when considering GHG

360 emissions as in Section 3.1. Electricity co-product also contributes to the strongly

361 negative PED value $(-6.85 \mathrm{MJ})$. The largest PED source is the manufacture of 
362 enzymes, contributing approximately $2.31 \mathrm{MJ} / \mathrm{MJ}_{\text {biofuel }}$ (total biorefinery demands 3.50

$363 \mathrm{MJ} / \mathrm{MJ}_{\text {biofuel }}$ ); Excluding waste treatment results in lower impacts being assessed for

364 the biofuel products, in contrast with the GWP results. Incineration of residual wastes

365 provides useful energy outputs, which are forgone when waste is diverted to the

366 biorefinery process. As such, if avoided waste treatment is excluded from the analysis,

367 net PED increases to $-17.8 \mathrm{MJ} / \mathrm{MJ}_{\text {biofuel }}$.

368 Results for the allocation approaches (RED I and II, mass, and economic allocation)

369 follow a similar pattern as those presented in Section 3.1 for GWP. Under RED I, a

370 reduction in PED of $23 \%$ relative to gasoline is achieved, as only the electricity co-

371 product credit is applied to products. For RED II, a significant share of energy use is

372 allocated to the heat and electricity co-products, and thus only a small PED

373 consumption is attributed to liquid biofuels, resulting in a $58 \%$ reduction relative to

374 gasoline. Similarly, mass allocation returns a PED reduction of $75 \%$ as only a small

375 share of production impacts are attributed to the biofuels. From an economic allocation

376 perspective, however, the biofuel products represent a large share of value of the 
377 product outputs (24\%) and are correspondingly attributed a large share of life cycle

378 PED, resulting in a net increase relative to gasoline of $60 \%$.

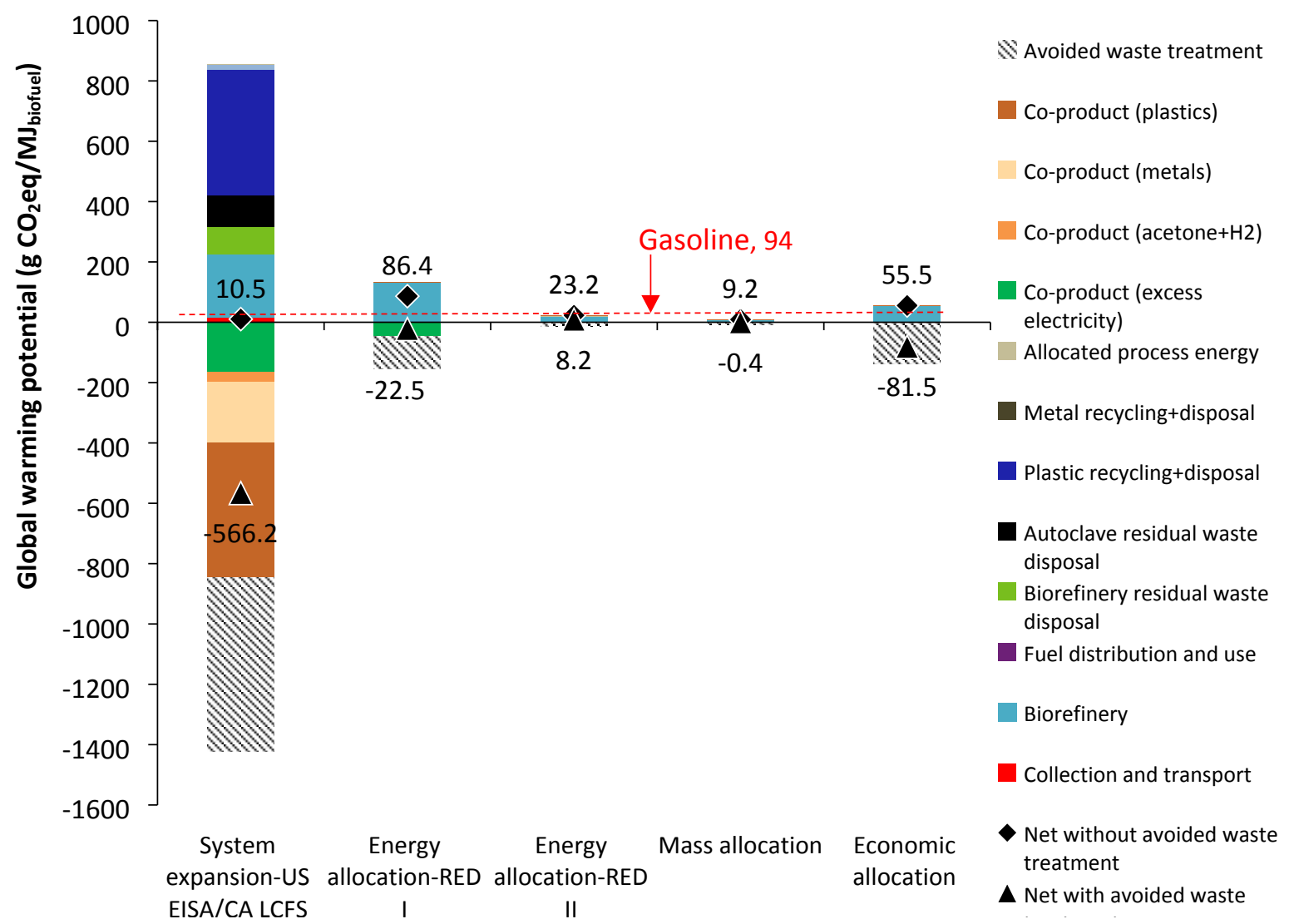




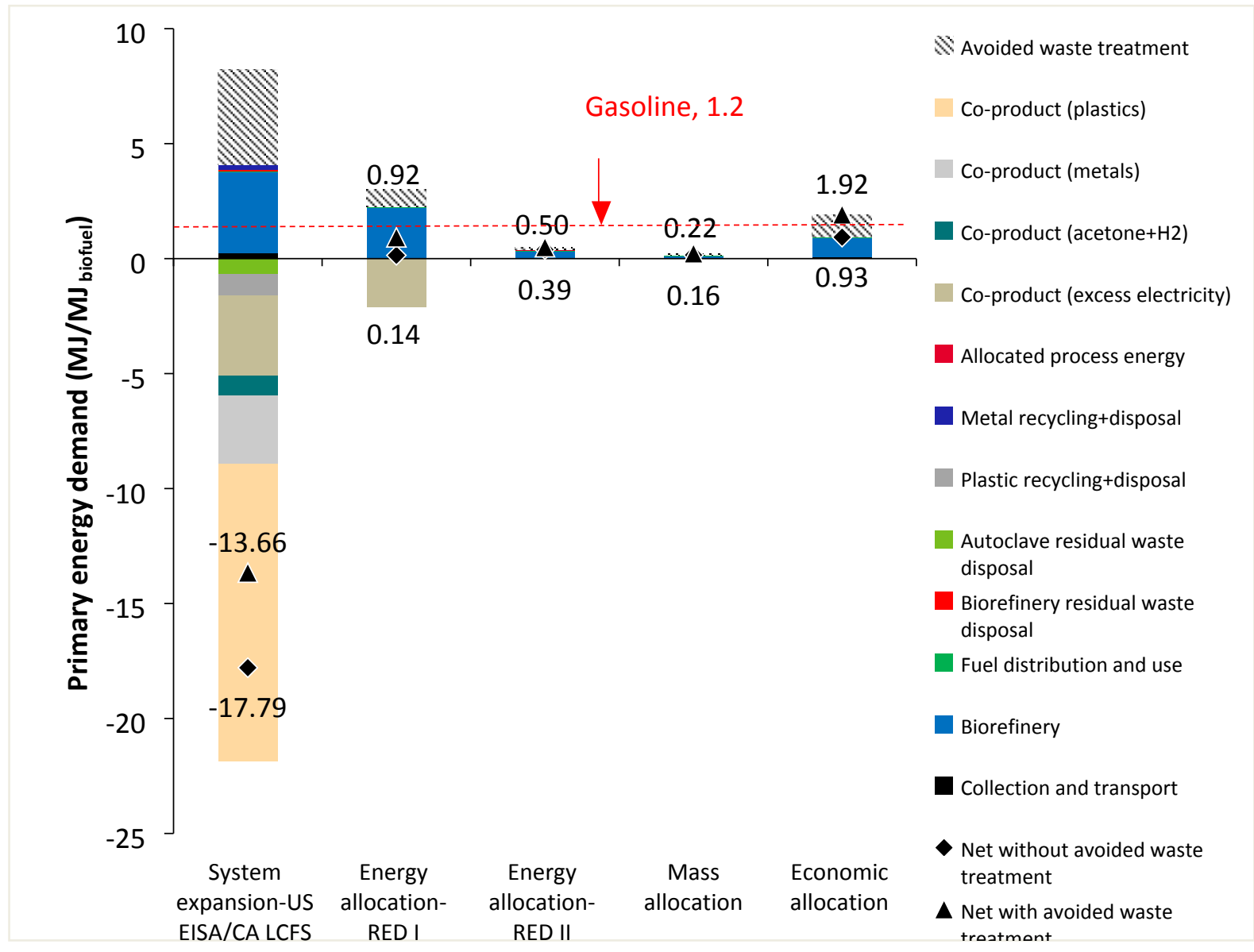

383 Figure 2 Life cycle global warming potential (a) and primary energy demand (b) of

384 MSW-derived liquid biofuel relative to reference fossil fuel based on different allocation

385 methods.

$386 \quad 3.3 \quad$ Comparison with other waste treatment routes

387 Presenting study results on the basis of 1 tonne MSW treated enables comparison

388 between waste management options. For this analysis, system expansion is employed 
389 for all waste treatment processes to understand the total impacts of the treatment 390 process and product outputs (including liquid biofuel use in place of gasoline). We 391 compare current case study results with conventional treatment processes: landfill 392 without biogas recovery, landfill with biogas recovery and incineration for energy 393 recovery (electricity only or CHP generation) (Figure 3). MSW conversion to liquid 394 biofuels is the superior option for both categories, achieving significantly greater 395 reductions in GHG emissions and PED than conventional waste treatment routes. 396 Without landfill gas capture, sanitary landfill operation emits the highest GHG 397 emissions of $573 \mathrm{~kg} \mathrm{CO}_{2}$ eq/t MSW; with landfill gas capture, the GWP of landfilling for 398 the electricity only and CHP options are 240 and $223 \mathrm{~kg} \mathrm{CO}$ eq/t MSW, respectively. 399 Increasing capture rate of biogas has been reported to be key in reducing the GWP of 400 the landfill option ${ }^{20}$. In comparison, incineration is a net source of GHG emissions, as 401 fossil $\mathrm{CO}_{2}$ emissions, largely from plastics combustion, exceed avoided emissions 402 associated with displacing heat and electricity production elsewhere. This results in 403 emissions of 174 and $58 \mathrm{~kg} \mathrm{CO}_{2} \mathrm{eq} / \mathrm{t} \mathrm{MSW}$ for the electricity-only and $\mathrm{CHP}$ incinerators, 
404 respectively. Incineration is able to recover useful energy from waste, indicated with 405 negative PED for both electricity and CHP scenarios (-3070 and $-4880 \mathrm{MJ} / \mathrm{t} \mathrm{MSW}$, 406 respectively. MSW conversion to liquid biofuels, alongside electricity, acetone, 407 hydrogen, and recyclates, delivers a far greater reduction in GWP (-30 kg $\mathrm{CO}_{2} \mathrm{eq} / \mathrm{t}$ $408 \mathrm{MSW})$ and PED (-10357 MJ/t MSW) than conventional waste treatment options 409 (disaggregated inputs can be found in Figure S8 in the SI). Further improvements 410 could be realised by finding markets for excess heat. In the current study, we assume 411 excess heat has no use. However, if the autoclave/biorefinery is integrated with other 412 industrial processes, district heating, or finds other uses (sterilization; cooling 413 generation), this would result in further reductions in GWP (110 kgCO 2 eq./t MSW) and 414 PED (1,700 MJ/t MSW). 


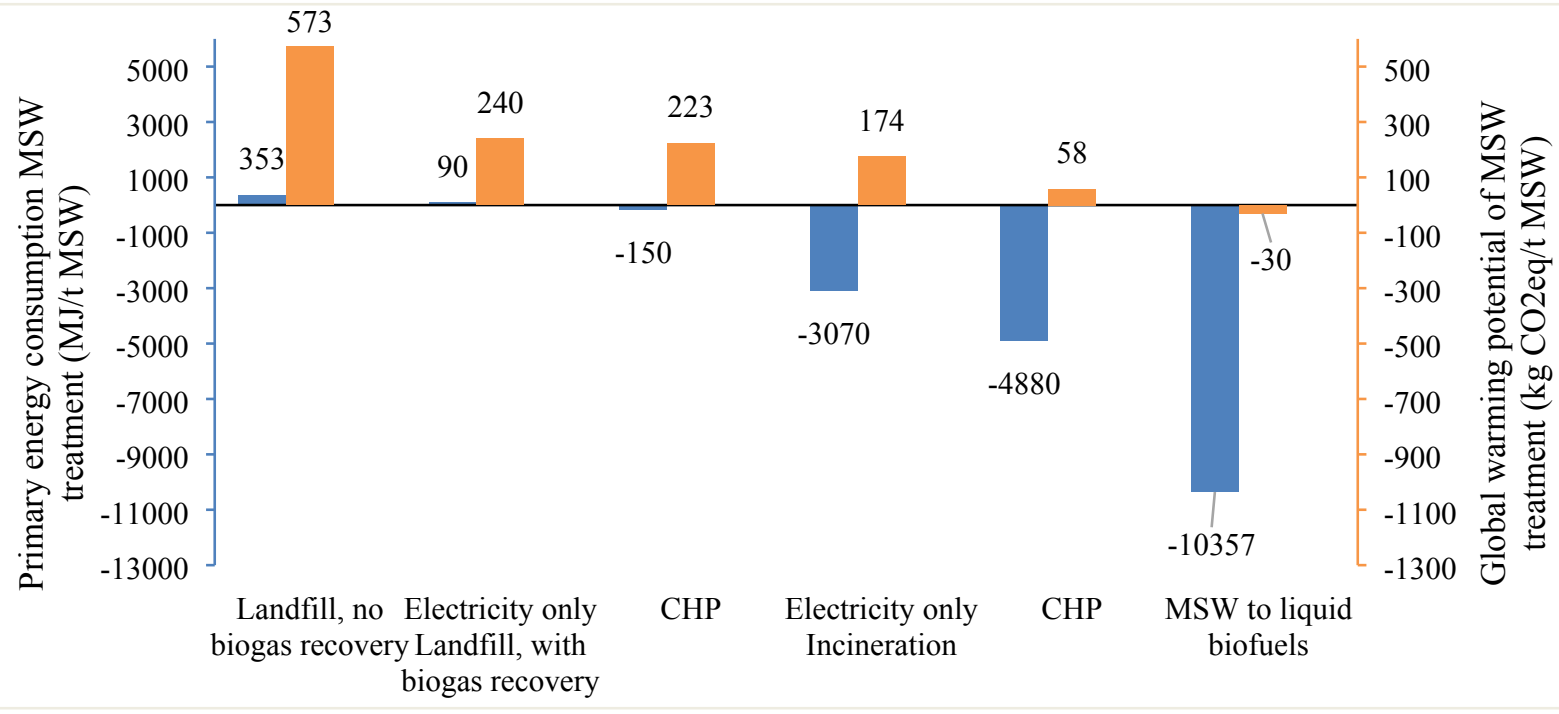

417 Figure 3 Life cycle primary energy demand (left axis) and global warming potential

418 (right axis) comparing MSW-derived liquid biofuels with landfill and incineration

419 options.

\section{$420 \quad 3.4 \quad$ Discussion}

421 The study evaluates alternative allocation methodologies for the life cycle evaluation

422 of waste-derived biofuels, considering a case study of butanol and ethanol production

423 from MSW. While biofuel production from MSW is demonstrated to reduce GHG

424 emissions and PED relative to gasoline, the magnitude of these reductions are

425 dependent on the allocation method employed. In practice, LCA researchers and 
426 policy makers have to select one allocation method that is most appropriate for the

427 analysis of biofuel systems. To do so requires careful consideration, as alternative

428 allocation methods are ultimately answering very different questions.

429 System expansion aims to understand the overall impact of introducing a new

430 product system. This approach benefits from its comprehensiveness in evaluating the

431 overall impact of the product system, but is based on a clear identification of biofuels

432 as the primary product and all other outputs as secondary. Where there are large co-

433 product outputs, associated credits can distort the results and risk not reflecting

434 stakeholder values or decision criteria. In the current study, significant electricity and

435 recovered metal co-products contribute to very negative emissions; avoided waste

436 treatment benefits are also solely attributed to the primary product. Whether it is

437 appropriate to consider liquid biofuels as a primary product is questionable, given that

438 this output represents only $24 \%$ of the financial value of system outputs, and

439 substantially less on energy (2.6\%) and mass (1.7\%) bases. 
440 An alternative approach to evaluate the overall impacts of waste conversion to

441 biofuels may be from the perspective of a waste treatment system - using a functional

442 unit of one tonne MSW, or equivalent - and thus taking into account all of the diverse

443 outputs of the system without having to artificially identify a single primary product.

444 Such results are not useful in biofuels policies that require a specific impact be

445 attributed to the biofuel product. However, such a framework could be appropriate for

446 a waste treatment sector-focused approach to evaluating and supporting higher value

447 products from waste (biofuels, bulk and high value chemicals, others), while

448 concurrently supporting diversion from conventional treatment routes.

449 In contrast, allocation approaches aim to attribute impacts to a specific, single

450 product. Allocation is, in theory, effective at isolating the impact of biofuel products

451 from the other outputs of the waste biorefinery system. However, the diversity of

452 products poses a challenge, as some cannot be addressed with energy allocation

453 (e.g., recovered metal, glass), and others cannot be addressed by mass allocation

454 (e.g., electricity, heat). Economic allocation may be more appropriate considering 
455 these issues, with further benefit of being able to better consider the motivations of

456 producers. However, this approach faces challenges including fluctuation of results

457 with market prices, and challenges of including non-monetisable goods within the

458 analysis.

459 A key question facing the analysis of waste-derived fuels is how avoided waste

460 treatment should be included within LCA calculations. Avoided waste treatment is

461 excluded in EU policy, but this approach ignores the "co-service" of waste treatment

462 provided by biofuel production and thus overestimates the impacts of waste-based

463 fuels. In contrast, system expansion gives full credit to biofuels for waste diversion,

464 despite this being but one product of the biorefinery system, and ignoring any other

465 changes occurring in the waste treatment sector, including those in response to policy

466 drivers to limit or reduce waste to landfill (and increasingly, to incineration). In future,

467 multiple viable opportunities may exist to utilise MSW, and therefore the role of a single

468 use in avoiding conventional waste treatment would be questionable. Sector

469 interactions are notoriously challenging for LCA to address (for example, induced land 
470 use change arising from crop-based biofuels), but should be pursued in future work to

471 ensure that the contexts of the energy and waste sectors are properly considered. At

472 present, by excluding the benefits of diverting wastes from landfill and incineration, EU

473 policy disadvantages biofuel production relative to other, lower-value uses of waste

474 streams.

475 Biofuel production from mixed wastes poses specific challenges to LCA practitioners

476 and policymakers. As illustrated in the current study, methodology decisions

477 dramatically influence results, with waste-derived biofuels either reducing GHG

478 emissions by $9 \%$ relative to gasoline under the EU's RED I policy, or by $700 \%$ using

479 system expansion as in US EISA and CA LCFS policies. Development of a relevant

480 LCA framework that can account for the complexities of waste biorefining is essential

481 to provide appropriate policy support for waste-derived fuels. 


\section{Associated Content}

483 The Supporting Information is available free of charge on the ACS Publications

484 website at DOI: $\mathrm{XXX}$.

485 Supporting Information includes additional details on the allocation method, figures

486 and tables that support the modelling and the results interpretation. Figures S1-S6

487 show the boundaries, flows and processes considered in the allocation methods.

488 Figures S7-9 shows the environmental efficiency of waste to biofuel, comparison with

489 other waste treatment routes and sensitivity analysis results. Table S1 summarises

490 the outputs of the autoclave and biorefinery process. Table S2 is an overview of

491 current biofuel regulations in the EU and US. Table S3 characterises the system

492 expansion method for MSW to ABE pathway. Table S4 presents characteristics and

493 values of exergy allocation for RED II methodology. Table S5 displays GHG emissions

494 of co-products under different allocation methods compared to Ecoinvent 3.3 values.

495 Table S6 presents life cycle GWP and PED of MSW-derived liquid biofuel relative to

496 reference fossil fuel based on different allocation methods corresponding to Figure 2. 
497

498 Author Information

499 Corresponding Author

500 *E-mail: Fanran.Meng@nottingham.ac.uk; phone: +44 01157487191

501 ORCID

502 Fanran Meng: 0000-0002-9014-1231

503 Jon McKechnie: 0000-0001-5656-1649

$504 \quad$ Notes

505 The authors declare no competing financial interest.

506 


\section{Acknowledgment}

508 This work was supported by the funding from the Bioenergy Sustaining the Future 2

509 MSWBH Project 620103. It was also funded by the Industrial Biotechnology Catalyst

510 (Innovate UK, BBSRC, EPSRC) to support the translation, development and

511 commercialisation of innovative Industrial Biotechnology processes.

\section{References}

513 (1) European Union Fuel Quality Directive. Fuel quality.

$514<$ https://ec.europa.eu/clima/policies/transport/fuel_en>, (accessed November 2018).

515 (2) Oregon Department of Environmental Quality (Oregon DEQ). Oregon Clean Fuels

516 Program. <https://www.oregon.gov/deq/aq/programs/Pages/Clean-Fuels.aspx>, (accessed 517 April 2019).

518 (3) British Columbia (BC). Renewable \& Low Carbon Fuel Requirements Regulation.

$519<\mathrm{https} / / / \mathrm{www} 2 . g o v . b c . c a / g o v / c o n t e n t /$ industry/electricity-alternative-energy/transportation-

520 energies/renewable-low-carbon-fuels $>$, (accessed April 2019).

521 (4) Luo, L.; van der Voet, E.; Huppes, G.; Udo de Haes, H. A. Allocation issues in LCA 522 methodology: a case study of corn stover-based fuel ethanol. Int. J. Life Cycle Ass. 2009, 14 523 (6), 529-539. 
524 (5) McKechnie, J.; Pourbafrani, M.; Saville, B. A.; MacLean, H. L. Exploring impacts of 525 process technology development and regional factors on life cycle greenhouse gas emissions 526 of corn stover ethanol. Renew. Energ. 2015, 76, 726-734.

527 (6) Murphy, C. W.; Kendall, A. Life cycle inventory development for corn and stover 528 production systems under different allocation methods. Biomass Bioenerg. 2013, 58, 67-75.

529 (7) Cai, H.; Han, J.; Wang, M.; Davis, R.; Biddy, M.; Tan, E. Life-cycle analysis of 530 integrated biorefineries with co-production of biofuels and bio-based chemicals: co-product 531 handling methods and implications. Biofuel Bioprod. Bior. 2018, 12 (5), 815-833.

532 (8) Buchspies, B.; Kaltschmitt, M. A consequential assessment of changes in greenhouse 533 gas emissions due to the introduction of wheat straw ethanol in the context of European 534 legislation. Appl. Energ. 2018, 211, 368-381.

535 (9) Ahlgren, S.; Björklund, A.; Ekman, A.; Karlsson, H.; Berlin, J.; Börjesson, P.; Ekvall, 536 T.; Finnveden, G.; Janssen, M.; Strid, I. Review of methodological choices in LCA of 537 biorefinery systems - key issues and recommendations. Biofuel Bioprod. Bior. 2015, 9 (5), 606538619.

539 (10) Liu, W.; Wang, J.; Richard, T. L.; Hartley, D. S.; Spatari, S.; Volk, T. A. Economic and 540 life cycle assessments of biomass utilization for bioenergy products. Biofuel Bioprod. Bior. $5412017,11(4), 633-647$.

542 (11) European Commission. Directive of the European Parliament and of the Council on 543 the Promotion of the Use of Energy from Renewable Sources (Recast); 2017.

544 (12) European Union. Directive 2009/28/EC of the European Parliament and of the Council 545 of 23 April 2009 on the promotion of the use of energy from renewable sources and amending 
546 and subsequently repealing Directives 2001/77/EC and 2003/30/EC. Off. J. Eur. Union 2009, $547 \quad 140,16-62$

548 (13) Buchspies, B.; Kaltschmitt, M. Life cycle assessment of bioethanol from wheat and 549 sugar beet discussing environmental impacts of multiple concepts of co-product processing in 550 the context of the European Renewable Energy Directive. Biofuels 2016, 7 (2), 141-153.

551 (14) Oconnell, A.; Edwards, R. Personal communication in RED rules with researchers from 552 Joint Research Centre, European Commission. In 2018.

553 (15) Unnasch, S. Avoided Life Cycle GHG Emissions from MSW Disposal, Life Cycle 554 Associates, Report No. LCA6060.120.2015; 2015.

555 (16) McKechnie, J.; Zhang, Y.; Ogino, A.; Saville, B.; Sleep, S.; Turner, M.; Pontius, R.; 556 MacLean, H. L. Impacts of co-location, co-production, and process energy source on life cycle 557 energy use and greenhouse gas emissions of lignocellulosic ethanol. Biofuel Bioprod. Bior. $558 \quad 2011,5(3), 279-292$.

559 (17) D'Avino, L.; Dainelli, R.; Lazzeri, L.; Spugnoli, P. The role of co-products in 560 biorefinery sustainability: energy allocation versus substitution method in rapeseed and 561 carinata biodiesel chains. J. Clean Prod. 2015, 94, 108-115.

562 (18) HM Revenue \& Customs. Policy paper- Landfill Tax: increase in rates; April 2019, 5632018.

564 (19) Kalogo, Y.; Habibi, S.; MacLean, H. L.; Joshi, S. V. Environmental Implications of 565 Municipal Solid Waste-Derived Ethanol. Environ. Sci. Technol. 2007, 41 (1), 35-41.

566 (20) Jeswani, H. K.; Azapagic, A. Assessing the environmental sustainability of energy 567 recovery from municipal solid waste in the UK. Waste Manage. 2016, 50, 346-363. 
568 (21) European Commission. Biofuels. <https://ec.europa.eu/energy/en/topics/renewable569 energy/biofuels>, (accessed January 2018).

570 (22) Department for Transport. Renewable Transport Fuel Obligation Annual Report 201657117.

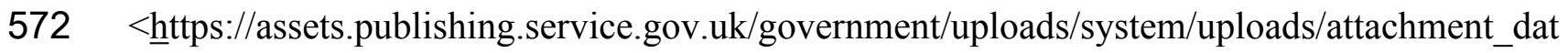
573 a/file/695185/rtfo-annual-report-2016-2017-web.pdf>, (accessed November 2018).

574 (23) International Organization for Standardization. ISO 14040: Environmental 575 Management: Life Cycle Assessment: Principles and Framework. 2006.

576 (24) International Organization for Standardization. ISO 14044: Environmental 577 Management, Life Cycle Assessment, Requirements and Guidelines. 2006.

578 (25) Stocker, T.; Qin, D.; Plattner, G.; Tignor, M.; Allen, S.; Boschung, J.; Nauels, A.; Xia, 579 Y.; Bex, B.; Midgley, B. IPCC, 2013: climate change 2013: the physical science basis. 580 Contribution of working group I to the fifth assessment report of the intergovernmental panel 581 on climate change. 2013.

582 (26) Department for Environmental Food and Rural Affairs (Defra). Digest of Waste and 583 Resource $\quad$ Statistics $\quad-\quad ~ 2017 \quad$ Edition.

$584<$ https://www.gov.uk/government/uploads/system/uploads/attachment_data/file/607416/Dige 585 st_of_Waste_and_Resource_Statistics_2017_rev.pdf $>$, (accessed August 2018).

586 (27) Department for Environmental Food and Rural Affairs (Defra). Statistics on waste 587 managed by local authorities in England in 2016-17.

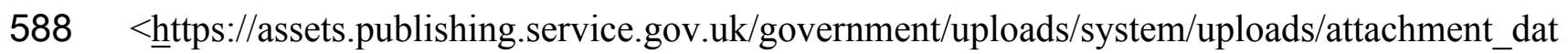
589 a/file/664594/LACW_mgt_annual_Stats_Notice_Dec_2017.pdf>,(accessed November 2018). 
590 (28) Wernet, G.; Bauer, C.; Steubing, B.; Reinhard, J.; Moreno-Ruiz, E.; Weidema, B. The 591 ecoinvent database version 3 (part I): overview and methodology. Int. J. Life Cycle Ass. 2016, $592 \quad 21(9), 1218-1230$.

593 (29) Meng, F.; Ibbett, R.; de Vrije, T.; Metcalf, P.; Tucker, G.; McKechnie, J. Process 594 simulation and life cycle assessment of converting autoclaved municipal solid waste into 595 butanol and ethanol as transport fuels. Waste Manage. 2019, 89, 177-189.

596 (30) Wilson Bio-Chemical. <http://wilsonbio-chemical.co.uk/the-wilson-system/>, 597 (accessed December 2017).

598 (31) WRAP (Waste \& Resources Action Programme). Composition of plastic waste 599 collected via kerbside; 2018.

600 (32) Shonfield, P. LCA of management options for mixed waste plastics. WRAP, UK 2008.

601 (33) Gabi. Gabi Extension Database VII Plastics. In 2014.

602 (34) Flanagan, J.; Davies, M. Glass recycling-life cycle carbon dioxide emissions. Sheffield: 603 British Glass, 45p 2003.

604 (35) Digest of UK Energy Statistics (DUKES). DUKES 2016 Chapter 5: Electricity. In 6052017. 